\title{
Winter ranging behaviour of a greater spotted eagle (Aquila clanga) in south- east Spain during four consecutive years
}

\section{Zimné teritoriálne správanie orla hrubozobého (Aquila clanga) v juhovýchodnom Španiel- sku počas štyroch za sebou nasledujúcich rokov}

\author{
Juan M. PÉREZ-GARCÍA, Urmas SELLIS \& Ülo VÄLI
}

\begin{abstract}
Knowing the winter behaviour is essential for deciding on conservation strategies for threatened migratory species such as the greater spotted eagle (Aquila clanga). Fidelity and inter-annual variation in winter home range of an Estonian greater spotted eagle were studied during the first four years of its life by means of GPS satellite telemetry in south-eastern Spain. Results show the eagle exploited a small area $\left(12.7 \mathrm{~km}^{2}, 95 \% \mathrm{kernel}\right)$ with high inter-annual fidelity during all winter stages. The $A$. clanga preferred marshes and water bodies and avoided irrigated crops and urban areas. Waterfowl hunting did not show any effect on the spatial pattern of the eagle's behaviour, although water level management in reservoirs could influence their use by the $A$. clanga. Our study highlights that the wintering home range may be limited to a small suitable habitat patch where human activities, especially water reservoir management, should be regulated.
\end{abstract}

\begin{abstract}
Abstrakt: Nevyhnutným predpokladom efektívnych ochranárskych opatrení je poznanie zimného správania ohrozeného migrujúceho druhu, akým je orol hrubozobý (Aquila clanga). Fidelita a medziročná variabilita charakteristík zimného okrsku jedinca orla hrubozobého pochádzajúceho z Estónska sa sledovala počas prvých štyroch rokov jeho života pomocou GPS-satelitnej telemetrie v juhovýchodnom Španielsku. Z výsledkov vyplýva, že orol využíval počas zimy len malé územie $(12,7$ km², 95 \%-ný kernel) s vysokou medziročnou fidelitou. A. clanga preferoval mokrade a vodné plochy a vyhýbal sa zavlažovaným pol'ným kultúram a urbanizovaným územiam. Pol’ovačky na vodné vtáctvo neovplyvnili charakter priestorového správania orla, avšak výška vodnej hladiny vodných rezervoárov mala vplyv na ich využitie sledovaným jedincom. $Z$ výsledkov našej štúdie možno zdôraznit, že zimný domovský okrsok môže byt' priestorovo obmedzený na malé plochy vhodného habitatu, kde by l'udská činnost', najmä manažment vodných rezervoárov, mala byt’ regulovaná.
\end{abstract}

Key words: fidelity, habitat selection, home range, human disturbance, satellite tracking, wetland management

Juan M. Pérez-García, Ecology Area, Department of Applied Biology, University Miguel Hernández, Avda Universidad S/N. E03202 Elche, Spain. E-mail: juanmapg@gmail.com.

Urmas Sellis, Eagle Club, Hauka, 63406 Valgjärve vald, Estonia. E-mail: urmas@kotkas.ee.

Ülo Väli, Department of Zoology, Institute of Agricultural and Environmental Sciences, Estonian University of Life Sciences, Riia 181, 51014 Tartu, Estonia. E-mail: ulo.vali@emu.ee.

Acknowledgements: We would like to thank the Estonian Environmental Board for permission to mark the eagle and for supporting the acquisition of tracking data. The project LIFE04NAT/ EE/000072 "Organising the protection of the black stork and spotted eagles in Estonia (EagleLife)" supported the purchase of the transmitter. We also thank the Hondo Natural Park for allowing access to the protected area. J.A. Sánchez-Zapata provided valuable comments on an earlier draft.

\section{Introduction}

Regarding threatened migratory raptors knowledge of their winter ecology is absolutely essential for deciding on conservation strategies (Newton 2007, Martin et al. 2007, Grande et al. 2009). The greater spotted eagle Aquila clanga is a migratory medium-large raptor that breeds in a fragmented range across temperate Eurasia and winters in Southern Eurasia and Northern Africa (del Hoyo et al. 1994). In Europe it winters primarily in Greece and western Turkey, and to a lesser extent in
Crete, Macedonia, Croatia and Italy (del Hoyo et al. 1994, Iankov et al. 1996, Maciorowski et al. 2014). Only a few wintering eagles occur more westerly (Iankov et al. 1996, Barrientos \& Bolonio 2002). A. clanga is listed as vulnerable (BirdLife International 2013), because it is suffering a moderately rapid decline as a result of habitat loss and degradation throughout its breeding and wintering ranges, together with the effects of disturbance, persecution and competition with other predators (BirdLife International 2013). Despite their 
importance for species conservation and management actions, to date only a few studies on ranging behaviour during the breeding season (Graszynski et al. 2002) and or migration routes and juvenile dispersal (Meyburg et al. 1998, 2005, Maciorowski et al. 2014) have been published. Knowledge of the eagles' ranging behavior during the wintering period is even scarcer. This period has been largely neglected and even basic knowledge, such as home range size, fidelity and use of space, is lacking (Graszynski et al. 2002).

Given the vulnerable state of conservation of this species, it is necessary to conduct winter home range studies to implement efficient conservation actions. Here, we use multi-year satellite-tracking data of an Estonian A. clanga wintering in south-eastern Spain in order to: (i) describe the winter home range and its core areas, (ii) analyse the fidelity and inter-annual changes in the home range during the first four years of the eagle's life, (iii) assess the interactions between home range and human activities and (iv) evaluate habitat selection during the winter season.

\section{Material and methods}

The study was conducted in the Hondo Natural Park in south-eastern Spain, $\left(38.17^{\circ} \mathrm{N}, 0.75^{\circ} \mathrm{W}\right.$, see Fig. 1). The Hondo Natural Park $\left(23.8 \mathrm{~km}^{2}\right)$ is formed by two main irrigation water reservoirs and several small wetlands and ponds. These reservoirs are subject to various uses and activities, such as controlling the water system to supply irrigation for agriculture, public use, hunting and fishing.

Between 2008 and 2011, a male A. clanga was tracked using a 45g Argos/GPS PTT satellite transmitter with solar panels (Microwave Telemetry Inc.). The eagle (called Tõnn) was equipped with the transmitter in Estonia $\left(59^{\circ} \mathrm{N}, 24^{\circ} \mathrm{E}\right)$ as a fledging (Fig. 2). The PTT was programmed to register locations up to November 20 every three hours between 9:00 $\mathrm{h}$ and 18:00 $\mathrm{h}$ (GMT), between 21 November and 20 February every three hours between 9:00 and 15:00 (GMT), and from 21 February every two hours between 6:00 and 18:00 (GMT).

For home range analysis we only selected locations when the bird was established in the wintering area, and we rejected the migration period. We defined the wintering area as a space where eagles' movements tend to concentrate and their movements are short and non-directional (Mellone et al. 2011). During four wintering seasons we obtained a total of 2,424 locations, with a mean per year of $606 \pm 79$ and a range of 537-711.
Home ranges were calculated separately for each winter season using Hawth's Tools (http://www.spatialecology.com) in ArcGis 9.0 (ESRI 2003). We calculated minimum convex polygon (MCP) and used fixed kernel (FK) methods to estimate $95 \%, 90 \%$ and $50 \%$ isopleths. The smoothing factor was calculated with $H_{\text {ref }}$ (Bowman

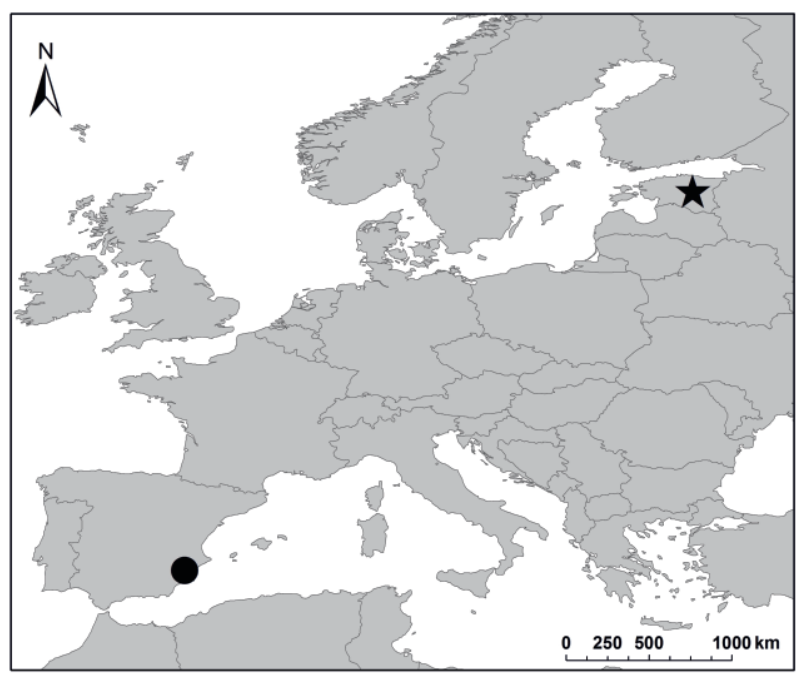

Fig. 1. Location of natal breeding area (star) and wintering area (full circle) of the Aquila clanga tracked in this study

Obr. 1. Lokalita rodiska (hviezda) a zimoviska (plný bod) orla hrubozobého sledovaného $v$ tejto štúdii

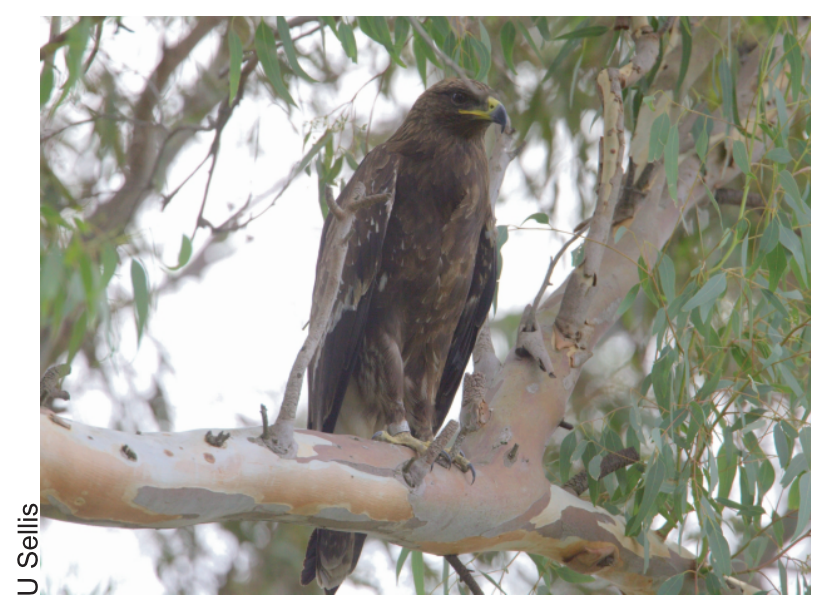

Fig. 2. Aquila clanga called "Tõnn" equipped with a transmitter in Estonia as a fledgling and which wintered for four consecutive seasons in the Hondo Natural Park (Spain). Picture taken on October 25, 2010 in the Hondo Natural Park

Obr. 2. Aquila clanga, pomenovaný "Tõnn", vybavený vysielačkou $v$ Estónsku ako mlád’a zimoval počas štyroch po sebe nasledujúcich rokov v prírodnom parku Hondo v Španielsku. Fotografované 25 . októbra 2010 v prírodnom parku Hondo 
et al. 1997). We calculated the accumulated home range, defined as the total area used by the tracked eagle during the whole monitoring period, and the winter home range fidelity, defined as the percentage of the total accumulated home range used during each winter season (McLoughlin \& Ferguson 2000, Pérez-García et al. 2013). We also evaluated inter-annual differences in home range sizes. Habitat selection was assessed by considering different land cover types; marshes and water surface, irrigated crops, dry crops, pine forest and scrublands, and urban developments. Land cover was obtained from CORINE 2006. Habitat representations were calculated in $50 \%$ and $90 \%$ kernels. To perform habitat selection, we compared the proportion of each habitat within the kernel with respect to total habitat available. We considered total MCP as the available habitat measure (Aebischer et al. 1993).

To study the influence of human management practices, we compared differences in numbers of locations between waterfowl hunting days (days when hunting is allowed in winter; Saturday and Sunday) vs non-hunting days (rest of the week). We also compared the numbers of locations per season at the main reservoirs with the principal activity at each of them (hunting or conservation) and with the water levels (high or low). For all these analyses we used Chi-square and Kruskal-Wallis tests. All tests were conducted in R-project (R Development Core Team 2012) with statistical significance based upon two-tailed tests at $p<0.05$. All the measurements are given with their mean and standard deviation.

\section{Results}

During the four study seasons, the tracked eagle arrived at the wintering areas between October $1^{\text {st }}$ and December $10^{\text {th }}$ and departed between March $26^{\text {th }}$ and April $13^{\text {th }}$ (Tab. 1). Average length of wintering was 152.5 days (range 124-182 days). The eagle exploited a small area during the wintering stages; mean home ranges were $258.6 \pm 161.7 \mathrm{~km}^{2}$ at $\mathrm{MCP}$, but only $8.2 \pm 3.7 \mathrm{~km}^{2}$ at $\mathrm{K}$ $90 \%$, and $1.0 \pm 0.4 \mathrm{~km}^{2}$ at $\mathrm{K} 50 \%$ (Tab. 1). No significant differences were found between wintering seasons at any of the home range scales (Kruskal-Wallis test: all $\mathrm{p}>0.05)$. Accumulated home range stabilized after the second monitoring season at $16.9 \mathrm{~km}^{2}$ (at $\mathrm{K} \mathrm{90 \%} \mathrm{level)}$ and for the core area ( $\mathrm{K} \mathrm{50 \% )}$ ) after the third season at $2.0 \mathrm{~km}^{2}$ (Tab. 1). Only $9.9 \%$ of the accumulated home range (K 90\%) was regularly used during all the monitored wintering seasons $(n=4)$, while $53.5 \%$ was used only during a single season.

The eagle preferably used marshes and water bodies (K 90\% $\chi_{1}^{2}=107.8, \mathrm{p}<0.01$; Tab. 2) and rejected irrigation crops $\left(\mathrm{K} 90 \% \chi_{1}^{2}=64.7, \mathrm{p}<0.01\right)$. Although we detected an increase in the use of these crops through the study period (K 90\%; $\chi_{3}^{2}=21.9, \mathrm{p}<0.01$ ). $85.6 \%$ of locations were inside the Natural Park, but the eagle did not use the same areas equally in each winter season. During the first two years he stayed mainly in the north of the park, whereas in the last two study years the western reservoirs were used $\left(\chi_{3}^{2}=315.1, \mathrm{p}<0.01\right.$; see Fig. 3). The eagle tended more frequently to use reservoirs with low water level $(37.7 \pm 14.0 \%$ vs $18.5 \pm$ $15.4 \%$; Kruskal-Wallis, $\mathrm{H}_{1}=2.88, \mathrm{p}=0.08$ ), while no differences were found in spatial use between hunting and non-hunting reservoirs (Kruskal-Wallis, $\mathrm{H}_{1}=1.14$, $\mathrm{p}=0.2$ ), nor in the spatial locations during waterfowl hunting days (Kruskal-Wallis, $\mathrm{H}_{1}=0.42, \mathrm{p}=0.3$ ).

Tab. 1. Description of Aquila clanga wintering period in the Hondo Natural Park: dates of arrival and departure, total number of wintering days, estimates of home range size $\left(\mathrm{km}^{2}\right)$, and accumulated home range by size $\left(\mathrm{km}^{2}\right)$ and by accumulated percentage $(\%)$

Tab. 1. Charakreristiky zimovania a zimoviska jedinca Aquila clanga v prírodnom parku Hondo: datum príletu a odletu, počet dní strávených na zimovisku, odhad vel'kosti zimného okrsku $\left(\mathrm{km}^{2}\right)$ a kumulovaného zimného okrsku $v$ absolútnom $\left(\mathrm{km}^{2}\right)$ aj relatívnom (\%) vyjadrení

\begin{tabular}{|c|c|c|c|c|c|c|c|c|c|}
\hline \multirow[t]{2}{*}{$\begin{array}{l}\text { season / } \\
\text { sezóna }\end{array}$} & \multicolumn{3}{|c|}{$\begin{array}{l}\text { winter tracking period / } \\
\text { obdobie zimného sledovania }\end{array}$} & \multicolumn{2}{|c|}{$\begin{array}{l}\text { home range / } \\
\text { domáci okrsok } \\
\left(\mathrm{km}^{2}\right)\end{array}$} & \multirow[b]{2}{*}{ K 90\% } & \multirow[b]{2}{*}{ K 95\% } & \multicolumn{2}{|c|}{$\begin{array}{l}\text { accumulated home range / } \\
\text { kumulovaný domáci okrsok } \\
\left(\mathrm{km}^{2} ; \%\right)\end{array}$} \\
\hline & $\begin{array}{l}\text { arrival / } \\
\text { prílet }\end{array}$ & $\begin{array}{l}\text { departure / } \\
\text { odlet }\end{array}$ & $\begin{array}{l}\text { days / } \\
\text { dni }\end{array}$ & MCP & K 50\% & & & K 50\% & K 90\% \\
\hline 1 & 10 Dec 08 & 13 Apr 09 & 124 & 467.1 & 1.0 & 9.3 & 13.5 & $1.0(48.0 \%)$ & $9.3(50.2 \%)$ \\
\hline 2 & 1 Oct 09 & 1 Apr 10 & 182 & 217.7 & 0.8 & 5.0 & 9.4 & $1.4(66.7 \%)$ & $16.9(91.5 \%)$ \\
\hline 3 & 16 Oct 10 & 27 Mar 11 & 162 & 272.9 & 1.5 & 12.8 & 19.5 & $2.0(95.2 \%)$ & $18.1(98.0 \%)$ \\
\hline 4 & 5 Nov 11 & $26 \operatorname{Mar} 12$ & 142 & 76.6 & 0.7 & 5.5 & 8.5 & $2.1(100 \%)$ & $18.5(100.0 \%)$ \\
\hline
\end{tabular}

$\mathrm{MCP}=$ minimum convex polygon, $\mathrm{K} 90 \%=90 \%$ kernel, $\mathrm{K} 50 \%=50 \%$ kernel, $\mathrm{K} 95 \%=95 \%$ kernel $/$

$\mathrm{MCP}=$ minimálny konvexný polygón, $\mathrm{K} 90 \%=90 \%$ kernel, $\mathrm{K} 50 \%=50 \%$ kernel, $\mathrm{K} 95 \%=95 \%$ kernel 
Tab. 2. Habitat preferences of the Aquila clanga tracked in the Hondo Natural Park measured as differences between habitat percentage available, measured as minimum convex polygon (MCP), and home range used, measured as $90 \%$ and $50 \%$ kernels (K90\% and $\mathrm{K} 50 \%$, respectively). ${ }^{* *}=\mathrm{p}<0.01$

Tab. 2. Habitatové preferencie jedinca Aquila clanga sledovaného $v$ prírodnom parku Hondo vypočítané ako rozdiel medzi dostupným habitatom (zisteným pomocou minimálneho konvexného polygónu; MCP) a využívaným zimným domovským okrskom (charakterizovaným pomocou $90 \%$-ného a $50 \%$-ného kernelov; $\mathrm{K} 90 \%$ a K50\%). ${ }^{* *}=\mathrm{p}<0,01$

\begin{tabular}{lrcc}
\hline $\begin{array}{l}\text { habitat types / } \\
\text { typy habitatov }\end{array}$ & MCP & K90\% & K50\% \\
\hline marsh / water $^{1}$ & $12.5 \%$ & $73.2 \% \%^{* *}$ & $85.9 \% \%^{* *}$ \\
irrigation crops $^{2}$ & $70.3 \%$ & $24.7 \%$ & $14.1 \% \%^{* *}$ \\
urban development $^{3}$ & $5.0 \%$ & $2.1 \%$ & $0.0 \%$ \\
forest $/$ scrublands $^{4}$ & $9.0 \%$ & $0.0 \%$ & $0.0 \%$ \\
dry crops $^{5}$ & $2.7 \%$ & $0.0 \%$ & $0.0 \%$ \\
\hline
\end{tabular}

1) mokrade ( vodné plochy; ${ }^{2}$ ) zavlažované plodiny; ${ }^{3}$ ) sídla; ${ }^{4}$ ) lesy / kroviny; ${ }^{5}$ ) "suché plodiny", t.j. obilniny a pod.

\section{Discussion}

Although satellite tracking is nowadays a rather commonly used tool to study the spatial behaviour of large birds (Meyburg \& Fuller 2007), this is to our knowledge the first spatial analysis of the wintering behaviour of $A$. clanga. We also describe the development and fidelity of the wintering home range consecutively during the first four years of one eagle's life, which is a topic scarcely studied in European migratory raptors (Alerstam et al. 2006, García-Ripollés et al. 2010, Limiñana et al. 2012, Mellone et al. 2012). During its first winter migration, the eagle explored several regions in southeastern Spain before settling down in the Hondo Natural Park, while in the following years it returned earlier to the same area using more direct routes (Väli et al. unpubl. data). The high fidelity to wintering areas detected in our study is consistent with earlier findings by Meyburg \& Meyburg (2005) for A. clanga marked in northeast Poland. Many birds return to known stopover sites and wintering areas used year after year (Åkesson 2003), and they even follow very similar or identical migration routes in consecutive years (Alerstam et al. 2006), suggesting that raptors select areas at least in part on the basis of knowledge acquired in previous years (Mellone et al. 2012). Moreover, in other species juvenile birds usually follow adult individuals to learn migration pathways, stopover sites and wintering areas (Maransky \& Bildstein 2001, Panuccio et al. 2012).

The wintering home range used by the $A$. clanga was only $10 \mathrm{~km}^{2}$, which is much smaller than suspected (without satellite tracking) for the breeding home range (Cramp \& Simmons 1980, del Hoyo et al. 1994). The tracked eagle showed a preference for marshes, wetlands and coastal lagoons where its prey, such as coots, rats and waders, is abundant. Most of the sightings of this species in Spain in the last 30 years were recorded in these habitats, such as Doñana National Park, Empordá, Delta del Ebro and the Hondo (Barrientos \& Bolonio 2002). Sadly, in Mediterranean regions wetlands and marshes have been very strongly transformed (Blondel \& Aronson 1999). During the $19^{\text {th }}$ and $20^{\text {th }}$ centuries, these areas were dried and artificialized for growing irrigated crops such as rice and citrus orchards. In spite of small wetlands being already protected (as Specially Protected Areas or Natural Parks), human activities are still allowed in some of them. Some studies report that spotted eagles are intolerant of permanent human presence in their breeding territories (BirdLife International 2013), but in the studied wintering ground we did not detect any negative effect from hunters on the tracked eagle's behaviour. Both spatial and temporal effects could explain this: tourist activities are restricted to a small specific area, and waterfowl hunting only takes place around sunrise. The raptor however always selected perches to rest in the interior of the Natural Park, away from the hunting area. On the other hand, reservoir management could influence the eagle's behaviour, as we detected a tendency for it to use low-water reservoirs. These wetlands have wider shores, which make the potential prey, such as birds, amphibians or fishes, more available.

Probably most of the wintering population of $A$. clanga in Southern Europe is restricted to rather small fragments of wetlands. Many of these sites are currently insufficiently protected and influenced by agricultural intensification, urban development and aggressive land use practices. Additionally, shooting is a potential risk for this species in some of them (BirdLife International 2013). Our study indicates that the wintering home range, which is used regularly, may be rather restricted and limited to a small suitable habitat patch. This result has important implications for conservation efforts, since efficient protection is less demanding on limited resources, but it also implies that highly-localized disturbances or local management decisions may have important consequences for the species, e.g. water reservoir management. 

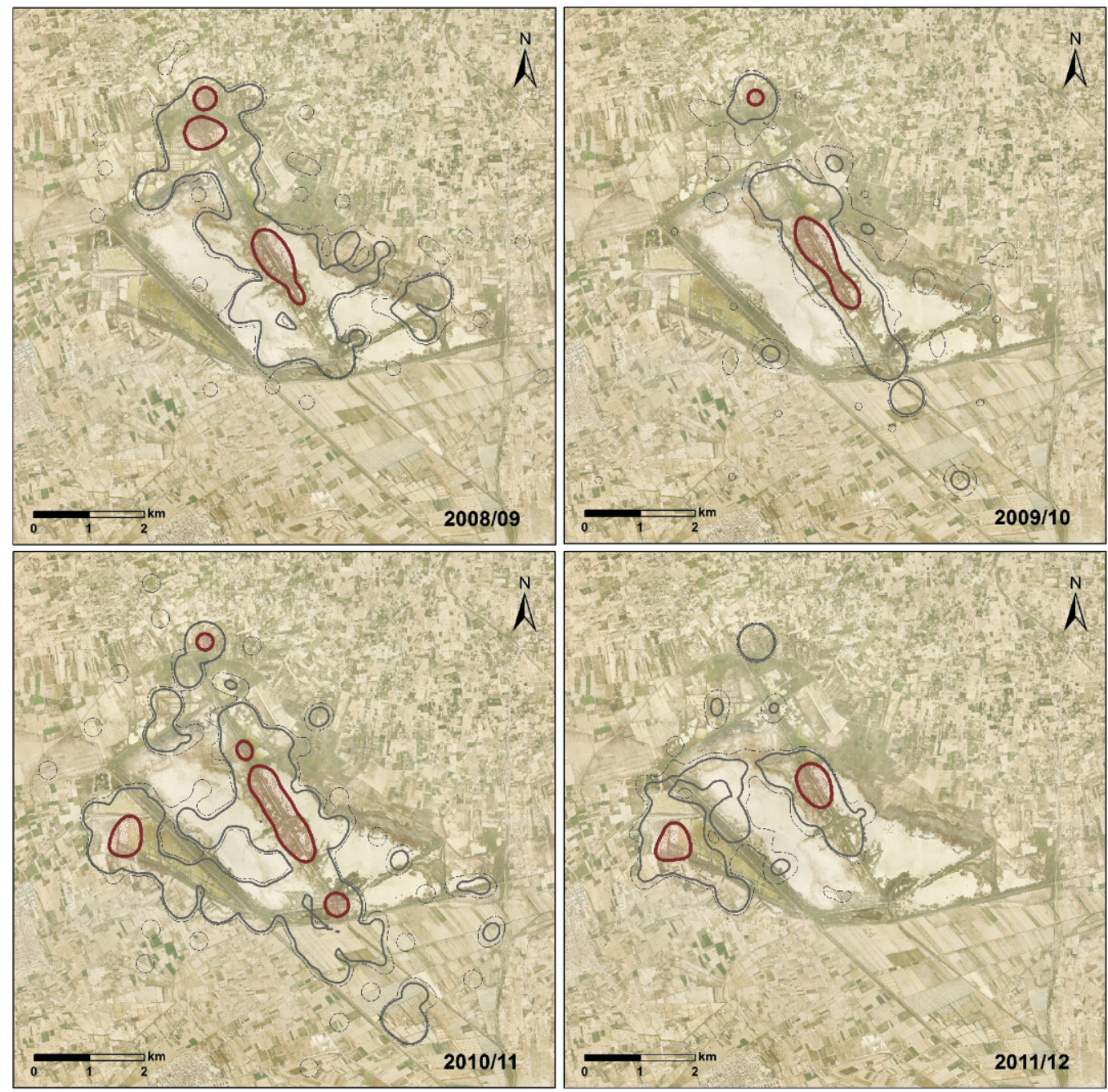

Fig. 3. Home ranges of a greater spotted eagle tracked in the Hondo Natural Park between 2008 and $2012(95 \%$ kernel $=$ bold line, $90 \%$ kernel $=$ simple line, and $50 \%$ kernel $=$ dotted line)

Obr. 3. Domáce okrsky orla hrubozobého zanamenané v prírodnom parku Hondo v rokoch 2008 až $2012(95 \%$ kernel = hrubá čiara, $90 \%$ = tenká čiara, and $50 \%=$ bodkovaná čiara)

\section{References}

Aebischer N, Robertson P \& Kenward R 1993: Compositional analysis of habitat use from animal radiotracking data. Ecology 74: 1313-1325.

Åkesson S 2003: Avian long-distance navigation: Experiments with migratory birds, 471-492. In: Berthold P \& Gwinner E (eds), Bird Migration. Berlin, Springer, 610.

Alerstam T, Hake M \& Kjellén N 2006: Temporal and spatial patterns of repeated journeys by ospreys: Implications for strategies and navigation in bird migration. Animal Behavior 71: 555-566. DOI: 10.1016/j.anbehav.2005.05.016

Alivizatos H, Papandropoulos D \& Zogaris S 2004: Winter diet of the Greater spotted eagle (Aquila clanga) in the Amvrakikos wetlands, Greece. Journal of Raptor Research 38: 371-374.

Bowman AW \& Azzalini A 1997: Applied smoothing techniques for data analysis. Clarendon Press, Oxford, 193.

Barrientos R \& Bolonio L 2002: Registros de Águila moteada (Aquila clanga) en la Península Ibérica. Ardeola 49: 293-296. [In Spanish with English summary] 
BirdLife International 2013: Species factsheet: Aquila clanga. Retrieved January 2, 2013 from http://www.birdlife.org

Blondel J \& Aronson J 1999. Biology and wildlife of the Mediterranean region. Oxford University Press, Oxford, 328.

Cramp S \& Simmons KEL (eds) 1980. Handbook of the Birds of Europe, the Middle East and North Africa. The birds of the Western Palaearctic. Oxford University Press, Oxford, 716.

del Hoyo J, Elliott A \& Sargatal J 1994: Handbook of the birds of the world. Lynx Editions, Barcelona, 638.

García-Ripollés C, López-López P \& Urios V 2010: First description of migration and wintering of adult Egyptian vultures Neophron percnopterus tracked by GPS satellite telemetry. Bird Study 57: 261-265. DOI: $10.1080 / 00063650903505762$

Grande JM, Serrano D, Tavecchia G, Carrete M, Ceballos O, Díaz-Delgado R, Tella JL \& Donázar JA 2009: Survival in a long-lived territorial migrant, effects of life history traits and ecological conditions in wintering and breeding areas. Oikos 118: 580-590. DOI: 10.1111/j.1600-0706.2009.17218.x

Graszynski K, Komischke B \& Meyburg B-U 2002: On the biology of the Greater Spotted Eagle (Aquila clanga Pallas 1811), 62-75. In: Yosef R, Miller ML \& Pepler D (eds). Raptors in the new millennium. International Birding and Research Center at Eilat. Eilat, Israel, 276.

Iankov P, Petrov T, Michev T \& Profirov L 1996: Status of the Spotted Eagle (Aquila clanga) and the Lesser Spotted Eagle (Aquila pomarina) in the Mediterranean, 77-89. In: Muntaner J \& Mayol J (eds). Biología y conservación de las rapaces mediterráneas. Sociedad Española de Ornitología, Madrid, 1994. [In Spanish with English summary]

Limiñana R, Soutullo A, Arroyo B \& Urios V 2012: Protected areas do not fulfil the wintering habitat needs of the trans-Saharan migratory Montagu's Harrier. Biological Conservation 145: 62-69. DOI: 10.1016/j.biocon.2011.10.009.

Maciorowski G, Lontkowski J \& Mizera T 2014: The spotted eagle - vanishing bird of the marshes. Agencja Promocyjno-Wydawnicza UNIGRAF, Bydgoszcz, 308.

Maransky BP \& Bildstein KL 2001: Follow your elders, age-related differences in the migration behavior of broad-winged hawks at Hawk Mountain Sanctuary, Pennsylvania. The Wilson Bulletin 113: 350-353.
Martin TG, Chadès I, Arcese P, Marra PP, Possingham HP \& Norris DR 2007: Optimal conservation of migratory species. PLoS ONE 2(8): e751. DOI: 10.1371/journal.pone.0000751

McLoughlin PD \& Ferguson SH 2000. A hierarchical pattern of limiting factors helps explain variation in home range size. Ecoscience, 7: 123-130.

Mellone U, Yáñez B, Limiñana R, Muñoz RA, Pavón D, González M, Urios V \& Ferrer M 2011: Summer staging areas of non-breeding short-toed snake eagles Circaetus gallicus. Bird Study 58:516-521. DOI: $10.1080 / 00063657.2011 .598914$

Mellone U, López-López P, Limiñana R \& Urios V 2012: Wintering habitats of Eleonora's falcons Falco eleonorae in Madagascar. Bird Study 59: 29-36. DOI: 10.1080/00063657.2011.632401

Meyburg B-U, Meyburg C, Mizera T, Maciorowski G \& Kowalski J 1998: Greater spotted eagle wintering in Zambia, Africa. Birds \& Birding 3: 62-68.

Meyburg B-U, Meyburg C, Mizera T, Maciorowski G \& Kowalski J 2005: Family break up, departure, and autumn migration in Europe of a family of Greater Spotted Eagles (Aquila clanga) as reported by satellite telemetry. Journal of Raptor Research 39: 465-469.

Meyburg B-U \& Meyburg C 2005: Tracking the Endangered Greater Spotted Eagle. Tracker News 6 (2): 4.

Meyburg B-U \& Fuller MR 2007: Satellite tracking, 242-248. In: Bird DM \& Bildstein KL (eds). Raptor research and management techniques. Hancock House Publishers, Surrey, Canada, 464.

Newton I 2007: The migration ecology of birds. Academic Press. London, 976.

Panuccio M, Agostini N \& Premuda G 2012: Ecological barriers promote risk minimisation and social learning in migrating short-toed snake eagles. Ethology, Ecology \& Evolution 24: 74-80.

Pérez-García JM, Margalida A, Afonso I, Gardiazabal A, Ferreiro E, Sánchez-Zapata JA \& Botella F 2013: Interannual home range variation, territoriality and overlap in breeding Bonelli's Eagle (Aquila fasciata) tracked by GPS satellite telemetry. Journal of Ornithology 154: 63-71. DOI: 10.1007/s10336-0120871-x

R Development Core Team 2012: R: A language and environment for statistical computing. R Foundation for Statistical Computing, Vienna, Austria. URL http://www.R-project.org. 